\title{
BERMAIN SAINS SEBAGAI METODE YANG EFEKTIF DALAM PEMBELAJARAN SAINS UNTUK ANAK USIA DINI
}

\author{
Oleh : \\ Gusti Ayu Dewi Setiawati ${ }^{1}$, Ni Wayan Ekayanti \\ ${ }^{1}$ Universitas Hindu Negeri I Gusti Bagus Sugriwa Denpasar, ${ }^{2}$ Universitas \\ Mahasaraswati Denpasar \\ Email: dewisetiawati@uhnsugriwa.ac.id
}

Diterima 15 September 2021, direvisi 29 September 2021, diterbitkan 1 Oktober 2021

\begin{abstract}
Abstrak
Anak usia dini merupakan masa perkembangan manusia yang fundamental atau dikenal dengan periode emas karena pada masa ini perkembangan fisik, intelektual, motorik, emosional, sosial dan bahasa anak sedang berlangsung dengan cepat. Sains harus dikenalkan sebagai bekal pengetahuan untuk anak usia dini yang terus tumbuh dan berkembang. Pengenalan sains pada anak usia dini merupakan upaya menumbuhkan sifat kritis, rasa ingin tahu, ketelitian, eksplorasi untuk mencari jawaban dan berpikir teratur melalui kegiatan menyenangkan. Sains dikenalkan sejak dini juga sebagai persiapan pembelajaran di jenjang yang lebih tinggi. Penelitian ini merupakan sebuah studi kepustakaan yang bertujuan untuk mengkaji kegiatan bermain sains sebagai metode yang efektif dalam pembelajaran sains untuk anak usia dini. Jenis kegiatan bermain sains yaitu: 1) bermain sains fisik, 2) bermain sains makhluk hidup dan 3) bermain sains bumi dan lingkungan. Berdasarkan hasil kajian literatur, diperoleh bahwa metode bermain sains efektif dalam pembelajaran sains di usia dini, di antaranya; meningkatkan kemampuan sains dan hasil belajar sains, mengenalkan dan meningkatkan keterampilan proses sains dasar serta meningkatkan konsep sains anak.
\end{abstract}

Kata Kunci: Bermain Sains, Pembelajaran Sains, Anak Usia Dini

\begin{abstract}
Early childhood is a period of fundamental human development or known as the golden period because at this time the physical, intellectual, motoric, emotional, social and language development of children is taking place rapidly. Science must be introduced as a provision of knowledge for early childhood who continues to grow and develop. The introduction of science in early childhood is an effort to foster critical character, curiosity, thoroughness, exploration to find answers and think regularly through fun activities. Science is introduced from an early age as well as preparation for learning at a higher level. This research is a literature study which aims to examine the activities of playing science as an effective method of learning science for early childhood. The types of activities in playing science are: 1) playing with physical science, 2) playing with the living things science and 3) playing on earth and environmental science. Based on the results of a literature review, it was found that the playing science method was effective in early age
\end{abstract}


science learning, including; improve science skills and science learning outcomes, introduce and improve basic science process skills and improve children's science concepts.

\section{Keywords: Playing Science, Science Learning, Early Childhood}

\section{PENDAHULUAN}

Tidak ada hal yang lebih menarik dari pendidikan. Dengan pendidikan manusia dapat menyesuaikan diri dengan lingkungan di mana berada dan mencapai hal yang diinginkannya, walaupun dengan berbagai cara yang dilakukan karena pendidikan adalah proses. Hal ini sejalan dengan (Dewey, 2013) yang menyatakan pendidikan adalah proses pembentukan kecakapan-kecakapan fundamental secara intelektual dan emosional ke arah alam dan sesama manusia. Pendidikan pada hakikatnya merupakan belajar yang berlangsung sepanjang hayat (long life learning). Dengan demikian pendidikan hendaknya diberikan sedari awal yakni pada masa anak usia dini.

Pendidikan bagi anak usia dini secara khusus diberikan melalui program Pendidikan Anak Usia Dini (PAUD). Keberadaan PAUD mulai menjadi tren dan semakin menunjukkan eksistensinya saat masyarakat telah menyadari pentingnya pendidikan di masa awal kehidupan manusia. Banyaknya hasilhasil penelitian neurosains dan psikologi terkini yang membuktikan bahwa potensi kecerdasan dan dasar perilaku seseorang terbentuk di usia dini memberikan andil terhadap meningkatnya eksistensi PAUD tersebut. Hasil penelitian yang dapat dipercaya menyatakan bahwa otak individu pada usia dini berkembang sangat pesat, hingga lebih dari $50 \%$ (Saepudin, 2011). Hal tersebut menyebabkan anak usia dini yaitu pada rentang usia 0-6 tahun, merupakan masa fundamental yang sangat penting bagi perkembangan seseorang karena akan berdampak pada masa depannya. Masa depan yang gemilang ditentukan oleh pendidikan anak usia dini yang berkualitas.

Maka dari itu, sejak dini anak harus dibekali dengan berbagai ilmu pengetahuan, di antaranya sains. Ilmu pengetahuan alam atau sains merupakan pengetahuan sistematis tentang alam dan dunia fisik, serta berarti pula pengetahuan sistematis yang diperoleh dari sesuatu observasi, penelitian, dan uji coba yang mengarah pada penentuan sifat dasar atau prinsip sesuatu yang sedang diselidiki, dipelajari, dan sebagainya (Kemendikbud, 2020). Sains merupakan pengetahuan sistematis tentang lingkungan di sekitar manusia yang diperoleh berdasarkan hasil observasi dan penelitian. Hasbi \& Wulandari (2020) menyatakan pengenalan sains pada anak usia dini bukan berarti belajar sains melainkan menumbuhkan sifat kritis, keingintahuan, teliti, eksplorasi untuk mencari jawaban dan berpikir teratur melalui kegiatan-kegiatan eksperimen yang menyenangkan. Terdapat suatu metode pembelajaran di PAUD yang dapat melatih anak mengenal gejala benda dan gejala peristiwa melalui kegiatan yang menyenangkan yaitu metode bermain sains.

Dengan karakter sains sebagai ilmu tentang alam yang sistematis, digabungkan dengan kegiatan belajar anak usia dini yang harus menyenangkan mengakibatkan 
perlunya pemahaman lebih dalam terkait metode bermain sains. Penelitian ini bertujuan mengkaji dari berbagai sumber tentang metode bermain sains sebagai bentuk metode pembelajaran pada jenjang PAUD serta mengetahui keefektifan metode bermain sains dalam pembelajaran sains anak usia dini.

\section{METODE}

Penelitian ini menggunakan metode studi kepustakaan atau literature review yang memanfaatkan berbagai pustaka untuk mengkaji permasalahan. Pustaka yang dikumpulkan berupa jurnal, artikel dan buku yang relevan dengan topik, kemudian melakukan interpretasi dan penafsiran terhadap sumber-sumber tersebut dan menyusunnya secara sistematis dan terstruktur. Hasil dari telaah berbagai pustaka tersebut digunakan untuk mengkaji kegiatan bermain sains sebagai metode yang efektif dalam pembelajaran sains untuk anak usia dini.

\section{PEMBAHASAN \\ Pembelajaran Sains}

Sains atau Ilmu Pengetahuan Alam (IPA) merupakan suatu konsep pengetahuan yang berasal dari bahasa latin scientia yang berarti pengetahuan. Sains yang dalam bahasa Inggris dikenal dengan istilah natural science atau umumnya science, merupakan kumpulan pengetahuan yang tersusun secara sistematis berdasarkan hasil observasi dan penelitian. Zubaidah (2011) menyatakan sains adalah pengetahuan yang sistematis dan tersusun secara teratur, berlaku umum (universal), dan berupa kumpulan data hasil observasi dan eksperimen, serta didefinisikan juga sebagai pengetahuan yang diperoleh melalui pengumpulan data dengan eksperimen, pengamatan, dan deduksi untuk menghasilkan suatu penjelasan tentang sebuah gejala yang dapat dipercaya. Beberapa kemampuan yang dapat diperoleh dari belajar sains, di antaranya; (1) mampu mengetahui apa yang diamati, (2) mampu memprediksi apa yang belum diamati, dan mampu menguji tindak lanjut hasil eksperimen dan dikembangkannya sikap ilmiah.

Pentingnya sains sering dikaitkan dengan teknologi, di mana sains dan teknologi pada akhirnya tidak terpisahkan. Teknologi ada untuk mempermudah hidup manusia, sedangkan keberadaan teknologi beserta penggunaannya memanfaatkan sains. Pengaruh perkembangan produk sains berupa teknologi semakin berkembang pesat yang mempengaruhi dunia ini. Belajar sains berarti belajar memahami diri (manusia) dan lingkungan sekitar (makhluk hidup, fisik dan kimia serta bumi dan antariksa). Segala tentang sains bersifat dinamis, artinya selalu berkembang mengikuti perubahan zaman. Sains berhubungan dengan segala jenis ilmu yang ada. Penguasaan sains yang diharapkan adalah secara utuh sehingga memperoleh pembahasan sains yang menyeluruh seperti konsep yang menyatakan sains for all, yang berarti sains untuk semua. Sains tidak hanya suatu ilmu semata tapi diharapkan dapat menyatu dalam kehidupan sehari-hari, lewat fenomenafenomena di alam yang ditemukan.

Pembelajaran dan sains adalah dua istilah yang tidak terpisahkan. Pembelajaran adalah suatu sistem, yang terdiri atas berbagai komponen yang saling berhubungan, meliputi tujuan, materi, metode dan evaluasi 
(Rusman, 2016). Pembelajaran membutuhkan proses yang disadari cenderung bersifat tetap dan mengubah perilaku (Thobroni, 2016). Pembelajaran sains adalah suatu proses yang menekankan pada keterampilan memperoleh pengetahuan dan mengembangkan sikap ilmiah. Pembelajaran sains merupakan sebuah proses memahami hakikat sains itu sendiri, yaitu rasa ingin tahu, proses, produk dan aplikasi/sikap. Dalam (Suastra, 2009) dinyatakan hakikat sains meliputi empat unsur yaitu: rasa ingin tahu, proses, produk dan aplikasi/sikap. Rasa ingin tahu mencakup rasa ingin tahu tentang benda, fenomena alam, makhluk hidup, serta hubungan sebab akibat yang menimbulkan masalah baru yang dapat dipecahkan melalui prosedur yang benar. Proses yaitu prosedur pemecahan masalah melalui metode ilmiah yang meliputi penyusunan hipotesis, perancangan eksperimen atau percobaan, evaluasi, pengukuran, dan penarikan kesimpulan. Produk terdiri dari fakta, prinsip, teori, dan hukum. Aplikasi atau sikap yaitu penerapan metode ilmiah dan konsep sains dalam kehidupan sehari-hari. Keempat unsur hakikat sains saling berkaitan dan diharapkan dapat muncul bersamaan dalam pembelajaran sehingga sains sapat dipahami secara utuh oleh peserta didik.

\section{Pentingnya Pembelajaran Sains Untuk Anak Usia Dini}

Anak usia dini merupakan masa perkembangan anak yang menarik untuk diamati. Hal ini disebabkan karena melibatkan proses kompleks, baik yang terjadi di dalam (fisiologis dan psikologis) maupun luar (lingkungan). Menurut UndangUndang No. 20 tahun 2003 tentang
Sistem Pendidikan Nasional yang disebut dengan anak usia dini adalah anak usia 0-6 tahun. Sedangkan banyak pakar atau ahli yang menyatakan bahwa anak usia dini adalah anak usia 0-8 tahun.

Anak dapat berkembang dan menerima pembelajaran melalui dua proses, yang dapat dijabarkan sebagai berikut: (1) pengalaman awal bagi anak bersifat kumulatif, artinya semakin sering maka pengaruhnya semakin besar, begitu pula sebaliknya, (2) belajar pada anak berlangsung dari pengetahuan behavioral yang sederhana ke pengetahuan yang simbolik atau representasional yang lebih kompleks Solehuddin \& Hatimah dalam (Saepudin, 2011). Dengan menilik dari cara anak berkembang dan menerima pembelajaran, maka sesungguhnya pembelajaran sains dapat diterapkan pada anak usia dini. Namun demikian, pembelajaran sains yang diterapkan pada anak usia dini masih sederhana dan bersifat pengenalan.

Pembelajaran sains penting ditanamkan sejak dini dengan tujuan yang sesuai dengan hakikat sains yaitu rasa ingin tahu, proses, produk dan aplikasi/sikap bagi anak usia dini. Tujuan pembelajaran sains bagi anak usia dini ditinjau dari hakikat sains yaitu sebagai berikut.

1) Rasa ingin tahu

Tidak ada yang dapat melebihi rasa ingin tahu yang dimiliki oleh anak usia dini karena ketertarikannya sangat tinggi pada dunia sekitar. Dengan tingginya rasa ingin tahu yang dimiliki anak usia dini maka sebaiknya pendidik menyiapkan jawaban yang ilmiah. Sains merupakan gudangnya penjelasan ilmiah sehingga dengannya rasa ingin tahu anak 
terfasilitasi dengan baik, yang mengakibatkan rasa ingin tahu anak nantinya dapat semakin berkembang.

2) Proses

Jika dihubungkan dengan dimensi proses sains, pembelajaran sains pada anak usia dini diarahkan pada penguasaan keterampilanketerampilan yang diperlukan dalam menggali dan mengenal sains. Anak pada akhirnya akan mengenal sains mengikuti proses ilmiah atau disebut metode ilmiah.

3) Produk

Terkait dengan dimensi produk sains, melalui pembelajaran sains diharapkan anak mengenal tentang fakta, konsep, teori maupun aspek lainnya. Secara sederhana berarti anak mendapat kumpulan pengetahuan sederhana, di mana anak diarahkan menjelaskan apa yang diketahuinya secara memadai kepada orang di sekitarnya.

4) Sikap

Tujuan pembelajaran sains pada anak usia dini terkait dimensi sikap yaitu secara bertahap diarahkan pada suatu pembentukan pribadi atau karakter yang baik dalam menemukan konsep pengetahuan layaknya seorang ilmuwan. Nantinya sikap sains akan menjadi penentu dalam mengembangkan kemampuan belajar sains di jenjang pendidikan selanjutnya.

Pentingnya pembelajaran sains dikenalkan sejak dini karena usia dini adalah masa keemasan perkembangan kognitif, sosial maupun emosional seseorang. Maka sangat baik mengenalkan sains sebagai upaya memberikan rangsangan atau stimulus yang baik. Perkembangan intelektual anak usia dini yang mencapai $50 \%$ dan menjadi $80 \%$ pada umur 8 tahun hendaknya menjadi kesempatan bagi orang tua dan pendidik lainnya untuk memberikan rangsangan atau stimulus yang terbaik. Manfaat pengenalan sains anak usia dini, yaitu; (1) menanamkan rasa cinta pada sains sejak dini, (2) memberikan pemahaman mendasar tentang konsep sains dan keterampilan berpikir, (3) mendukung perkembangan dalam bidang lainnya atau yang menyertainya dan (4) membantu menentukan pendekatan yang sesuai untuk pembelajaran sains sejak dini (First Discoverers, 2020). Pendidikan pada anak usia dini pada dasarnya meliputi seluruh upaya yang dilakukan oleh pendidik dan orang tua dengan menciptakan lingkungan di mana anak dapat memperoleh pengalaman yang memberikan kesempatan padanya untuk mengetahui dan memahami. Proses pembelajaran sebagai bentuk perlakuan yang diberikan pada anak harus memperhatikan karakteristik yang dimiliki setiap tahapan perkembangan anak.

Hasil penelitian menunjukkan bahwa di umur 7 tahun, sudah terlihat bahwa anak menyukai atau tidak sains tersebut. Dengan demikian kegiatan mengenalkan sains yang tepat sebelum umur 7 tahun tersebut akan membuat anak memiliki sikap positif atau menyukai sains yang berguna bagi masa depannya. Pembelajaran sains memberikan kesempatan anak untuk mengembangkan keterampilan hidup lainnya, seperti keterampilan berkomunikasi, berkolaborasi, bekerja sama dan tekun, berpikir analisis dan memecahkan masalah. Selain itu dapat pula membantu anak meningkatkan penguasaan kosakata ilmiah, merangsang perkembangan kemampuan literasi, numerasi dan kreativitas anak. Sebagian besar anak 
menyukai eksplorasi fisik sehingga dengan belajar sains akan memudahkan dalam merangsang serta mempertahankan fokus minat anak usia dini dalam belajar. Perkembangan anak usia dini di berbagai aspek juga akan berkembang dengan optimal jika diberi rangsangan yang tepat (First Discoverers, 2020).

\section{Metode Bermain Sains untuk Anak Usia Dini}

Metode pembelajaran adalah salah satu komponen dalam pembelajaran. Metode adalah cara yang ditempuh oleh pendidik agar tujuan pembelajaran yang ditetapkan dapat tercapai dengan baik. Dalam Rusman (2016) dinyatakan metode sebagai $a$ way in achieving something yaitu cara untuk memperoleh sesuatu dalam hal ini yaitu tercapainya tujuan pembelajaran. Kumpulan atau kolaborasi penggunaan metode pembelajaran diperlukan dalam merealisasikan strategi pembelajaran. Berbagai metode telah dikenal selama ini, di antaranya; ceramah, diskusi, demonstrasi, resitasi, eksperimen/percobaan, karya wisata, tanya jawab, dan bermain. Bermain adalah salah satu metode yang cocok diterapkan untuk anak-anak.

Bermain pada dasarnya adalah berbuat sesuatu untuk menyenangkan hati (dengan alat tertentu atau tidak) (Kemendikbud, 2020) dan merupakan hak anak. Bermain meningkatkan perkembangan kognitif anak serta membantu mengembangkan kreativitas, kemampuan memecahkan masalah dan berkomunikasi. Bermain dapat mempengaruhi perkembangan jiwa anak. Terdapat dua macam permainan, yaitu permainan aktif dan pasif. Permainan aktif misalnya; bermain bebas, spontan atau eksplorasi, drama, musik, mengumpulkan atau mengoleksi sesuatu, olah raga. Sedangkan contoh permainan pasif, yaitu; membaca, mendengarkan radio dan menonton televisi ((Sudarna dalam (Zaini, 2019). Bermain merupakan cara belajar yang sangat penting bagi anak karena bermain adalah dunia anak.

Kegiatan bermain untuk anak sangat penting sehingga pembelajaran sains untuk anak usia dini sangat tepat jika menggunakan metode bermain, yang disebut dengan bermain sains. Bermain sains merupakan kegiatan untuk meningkatkan aspek perkembangan dan potensi yang dimiliki anak. Bermain sains ditujukan untuk melatih kemampuan anak mengenal berbagai gejala benda dan gejala peristiwa. Anak dilatih untuk melihat, meraba, membau, merasakan, mendengar dan mengecap. Semakin banyak keterlibatan indra dalam belajar, anak semakin memahami apa yang dipelajari. Anak memperoleh pengetahuan baru dari hasil pengindraannya dengan berbagai benda yang ada di sekitarnya. Tujuan bermain sains yaitu: (1) mengenalkan dan memupuk rasa cinta kepada alam sekitar sehingga menyadari kebesaran dan keagungan Tuhan yang Maha Esa, (2) menumbuhkan minat pada anak usia dini untuk mengenal dan mempelajari benda-benda serta kejadian di lingkungan sekitarnya, (3) mengembangkan aspek-aspek yang terkait dengan keterampilan sains dasar seperti mengamati, mencari tahu, melakukan, menemukan, dan menyampaikan temuanny sehingga pengetahuan dan gagasan tentang alam sekitar dalam diri anak menjadi berkembang, (4) mengembangkan rasa ingin tahu, tekun, terbuka, kritis, mawas diri, bertanggung jawab, bekerja sama, dan mandiri dalam 
kehidupannya, dan menggunakan teknologi sederhana dan konsep sains yang dapat digunakan untuk memecahkan masalah yang ditemukan dalam kehidupan seharihari (Hasbi \& Wulandari, 2020).

Sains terdiri dari tiga dimensi kajian, yang dapat diamati melalui Tabel 1.

Tabel 1. Sains Berdasarkan Dimensi yang Dipelajari

\begin{tabular}{|c|c|c|}
\hline No. & $\begin{array}{l}\text { Kelompok } \\
\text { Materi }\end{array}$ & Topik Utama \\
\hline 1 & Fisika-Kimia & $\begin{array}{l}\text { Ilmu tentang energi, } \\
\text { usaha, bahan-bahan } \\
\text { kimia dan reaksinya }\end{array}$ \\
\hline 2 & Biologi & $\begin{array}{l}\text { Ilmu tentang } \\
\text { tumbuhan, hewan dan } \\
\text { hubungan makhluk } \\
\text { hidup dengan } \\
\text { lingkungannya }\end{array}$ \\
\hline 3 & $\begin{array}{l}\text { Bumi dan } \\
\text { Antariksa }\end{array}$ & $\begin{array}{l}\text { Pengetahuan tentang } \\
\text { bintang, matahari dan } \\
\text { planet, tanah, batuan, } \\
\text { dan pegunungan serta } \\
\text { ilmu tentang cuaca dan } \\
\text { musim }\end{array}$ \\
\hline
\end{tabular}

Sumber: (Nurkholisoh, 2019)

Dengan mengaitkan antara kelompok materi beserta topik yang dipelajari, maka dalam metode bermain sains untuk anak usia dini juga mengandung ketiga lingkup materi yang terdiri dari; bermain sains fisik, bermain sains makhluk hidup dan bermain sains bumi dan lingkungan (Hasbi \& Wulandari, 2020; Adit, 2019).

1) Bermain Sains Fisik

Dalam bermain sains fisik, anak diajak untuk mengenal wujud fisik dari benda melalui eksplorasi, belajar ciri- ciri benda, cara benda bergerak, perubahan pada benda (berat, bentuk, ukuran, warna dan temperatur) serta mengeksplorasi bagaimana benda-benda bergerak dan berubah. Beberapa kegiatan bermain sains fisik yang bisa dilakukan misalnya: mengenal es mencair, membuat susu, bola menggelinding, mengenal rasa makanan, mencium bau dan mengenal macam- macam bentuk dari benda atau buah.

2) Bermain Sains Makhluk Hidup Melalui sains makhluk hidup, anak diajak mengeksplorasi tentang makhluk hidup seperti manusia, hewan, dan tumbuhan. Anak diajak mengenal ciri, siklus dan tempat hidup makhluk hidup. Beberapa kegiatan bermain sains yang dapat dilakukan, misalnya: mengamati perubahan dari kacang hijau menjadi tauge, memotong dan mencuci sayuran, memetik buah atau daun, menanam tanaman, merawat binatang peliharaan dan mengamati akuarium sebagai tempat hidup makhluk hidup.

3) Bermain Sains Bumi dan Lingkungan

Bermain sains bumi dan lingkungan mengajak anak mengenal alam sekitar yang diamati langsung oleh anak, seperti mengenal benda angkasa (bulan, bintang dan matahari dan planet), menggambar rumah dan lingkungan sekitar, mewarnai gambar lingkungan, mengamati terjadinya hujan, mengetahui bahwa membuang sampah sembarangan dapat mengakibatkan banjir. Melalui bermain sains bumi dan lingkungan, anak mengenal tentang sebab akibat, dan mengenal peran manusia yang dapat berakibat positif maupun negatif bagi lingkungannya.

Bermain sains merupakan kegiatan yang sifatnya pengenalan bagi anak terhadap sains sehingga sifatnya sederhana, ringan namun menyenangkan bagi anak. Kegiatan 
ini tidak hanya dapat dilakukan oleh pendidik di sekolah/guru PAUD saja, melainkan dapat dilakukan oleh orang tua. Guru dan orang tua dapat berkolaborasi untuk mengenalkan sains secara optimal bagi anak. Penerapan bermain sains dapat dilakukan sehari-hari dikaitkan dengan dunia sains meskipun tidak semuanya bisa dijelaskan pada anak usia dini. Guru dan orang tua harus pandai memilih aktivitas-aktivitas mana yang bisa diiringi dengan upaya mengenalkan sains pada anak. Melalui aktivitas ringan sehari-hari, misalnya dengan bermain di halaman rumah, orang tua dapat menjelaskan kondisi cuaca dan perubahannya yang berakibat boleh atau tidaknya anak bermain di luar rumah sesuai dengan perubahan cuaca yang terjadi. Mendorong anak menggunakan indra untuk mengamati benda-benda kemudian menggambarkan suara, tekstur, bau, warna di mana cara ini dapat membantu mengembangkan kosakata dan keterampilan observasinya. Agar penjelasan yang diberikan pada anak tampak semakin nyata maka sediakanlah buku-buku sains untuk anak usia dini yang mampu menarik perhatian dan tidak membosankan. Cara lainnya yang dapat ditempuh adalah mengajak anak mengadakan kegiatan percobaan sederhana (Hasbi \& Wulandari, 2020).

Bermain sains dapat dilakukan dengan beragam hal di sekitar, namun tetap diperhatikan bahwa kriteria dari permainan sains yang diberikan harus sesuai dengan tingkat perkembangan anak usia dini, antara lain yaitu; memperlihatkan secara langsung hubungan sebab akibat, memungkinkan anak melakukan eksplorasi, memungkinkan anak membangun pengetahuan sendiri, memungkinkan anak menjawab persoalan "apa" daripada "mengapa", lebih menekankan pada proses daripada produk, memungkinkan anak menggunakan bahasa dan matematika dan menyajikan kegiatan yang menarik (the wonder of science) (Suyanto, 2008).

\section{Metode Bermain Sains Efektif Dalam Pembelajaran Sains Anak Usia Dini}

Berdasarkan hasil kajian dari berbagai literatur, diperoleh bahwa metode bermain sains efektif digunakan untuk pembelajaran sains di usia dini. Salim et al., (2014) melalui penelitiannya menemukan bahwa metode bermain balon jet dan replika gunung meletus dengan model inkuiri dapat meningkatkan kemampuan sains anak usia dini yaitu pada kelompok B TK Mojokerto 3 Kedawung Sragen. Melalui kegiatan bermain, guru tidak hanya dapat bermain bersama tetapi juga mengamati aktivitas anak dan menentukan peningkatan kemampuan sains yang dimiliki anak. Hal ini juga sejalan dengan temuan (Yulianti et al., 2011) yaitu penerapan bermain dalam pembelajaran di Kelas B Taman Kanak-kanak Aisyiyah Bustanul Athfal 38 Kota Semarang dapat meningkatkan hasil belajar sains anak yang mencakup kognitif, efektif dan psikomotor. Melalui hasil penelitian diperoleh hasil belajar kognitif yang meningkat meliputi kemampuan mengamati, mengkomunikasikan, memperkirakan penyebab, mengklasifikasi, memecahkan masalah dan membuat keputusan. Hal tersebut disebabkan kegiatan bermain yang dirancang membuat anak memiliki kesempatan untuk bereksplorasi, menemukan, 
mengekspresikan perasaan, berkreasi, belajar secara menyenangkan.

Metode bermain sains ternyata juga efektif meningkatkan kemampuan berpikir kritis anak usia dini, seperti temuan (Kriswidyantari et al., 2016) pada anak kelompok A1 semester II TK Negeri Pembina Denpasar tahun akademik 2015/2016. Indikator berpikir kritis yang digunakan untuk mengobservasi kemampuan berpikir kritis pada anak antara lain; 1) menunjukkan aktivitas yang bersifat eksploratif dan menyelidik, 2) menunjukkan inisiatif bertanya atau menjawab pertanyaan, 3) mengenal dan memprediksi sebabakibat, 4) memecahkan masalah sederhana dibantu oleh orang dewasa. Walaupun menggunakan indikator berpikir kritis yang sederhana, namun penelitian ini menunjukkan efektifnya metode bermain sains dalam meningkatkan keterampilan berpikir yang merupakan salah satu kecakapan hidup abad 21 yang harus dimiliki oleh peserta didik di era 4.0.

Selain dapat meningkatkan keterampilan berpikir, metode bermain sains juga dapat mengenalkan anak pada keterampilan proses sains dasar. Komponen utama dalam keterampilan proses sains dasar, yaitu mengamati, membandingkan, mengklasifikasi, mengukur dan mengkomunikasikan. Serangkaian kegiatan tersebut dipadukan dalam permainan tentang objek dan fenomena alam, seperti bermain detektif menunjuk kegiatan penyelidikan dengan seluruh alat indera atau bermain sebagai ilmuan mengungkap fenomena alam (Rahmi, 2019). Hal serupa juga ditemukan (Rahardjo, 2019) yaitu dengan metode bermain sains makhluk hidup dipadukan pendekatan saintifik dapat membentuk keterampilan proses anak usia dini. Selain itu melalui bermain juga yaitu mengenal peristiwa mengapung dan tenggelam sebagai pengenalan sains di RA Masjid AlAzhar Ngaliyan Semarang, konsep sains yang dimiliki anak meningkat karena proses belajar menjadi lebih bermakna (Munawaroh, 2017).

Beberapa hasil penelitian tersebut menunjukkan efektifnya metode bermain sains dalam pembelajaran sains untuk anak usia dini. Hal tersebut dapat menjadi inspirasi dalam mengembangkan penelitian atau pun mengkaji bahwa dengan metode bermain sains anak usia dini dapat belajar sains.

\section{SIMPULAN}

Sains atau Ilmu Pengetahuan Alam (IPA) adalah pengetahuan yang sistematis dan tersusun secara teratur, berlaku universal berupa kumpulan data hasil observasi dan eksperimen. Dengan menilik dari cara anak berkembang dan menerima pembelajaran, maka sesungguhnya pembelajaran sains dapat diterapkan pada anak usia dini. Namun demikian, pembelajaran sains yang diterapkan pada anak usia dini masih sederhana dan bersifat pengenalan. Pembelajaran sains penting ditanamkan sejak dini dengan tujuan yang sesuai dengan hakikat sains yaitu rasa ingin tahu, proses, produk dan aplikasi/sikap. Kegiatan bermain untuk anak sangat penting sehingga pembelajaran sains untuk anak usia dini sangat tepat jika menggunakan metode bermain, yang disebut dengan bermain sains. Kegiatan bermain sains dikelompokkan menjadi tiga, yaitu: bermain sains fisik, bermain sains makhluk hidup dan bermain sains bumi dan lingkungan. Bermain sains merupakan kegiatan untuk meningkatkan aspek perkembangan 
dan potensi yang dimiliki anak. Metode bermain sains memang efektif dalam pembelajaran sains pada anak usia dini, di antaranya; dapat meningkatkan kemampuan sains dan hasil belajar sains, mengenalkan dan meningkatkan keterampilan proses sains dasar serta meningkatkan konsep sains anak.

\section{DAFTAR PUSTAKA}

Adit, A. (2019). 3 Cara Mudah Bermain Sains Bersama Anak Usia

Dini.

https://edukasi.kompas.com/read /2020/06/29/073915371/3-caramudah-bermain-sains-bersamaanak-usia-dini?page $=$ all

Dewey, J. (2013). Dasar-Dasar Ilmu Pendidikan. PT. RajaGrafindo Persada.

First, D. (2020). Why Science Education is Important in Early Childhood.

https://www.firstdiscoverers.co.u $\mathrm{k} /$ science-education-earlychildhood/

Hasbi, M., \& Wulandari, R. (2020). Bermain Sains (F. Amrullah (ed.)). Kementerian Pendidikan dan Kebudayaan. https://anggunpaud.kemdikbud.g o.id/images/upload/images/2020/ 12_buku_BDR/Bermain_Sains2.pdf

Kemendikbud. (2020). Kamus Besar Bahasa Indonesia. In Dictionary (2020th ed.). Kemdikbud. https://kbbi.kemdikbud.go.id/ent ri/model

Kriswidyantari, N., Sujana, I. W., \& Wiyasa, I. K. N. (2016). Penerapan Permainan Sains untuk Meningkatkan Kemampuan Berpikir Kritis Anak Kelompok A1 Tk Negeri Pembina Denpasar. Pendidikan Anak Usia Dini Undiksha, 4(2).
Munawaroh, H. (2017). Implementasi Pembelajaran Sains AUD Melalui Permainan Terapung dan Tenggelam di RA Masjid Al-Azhar Bukit Permata Puri Kec. Ngaliyan Kota Semarang. Wahana Akademika, 4(2).

Nurkholisoh, D. (2019). Science Concepts in Early Childhood Education. The 2nd International Conference on Elementary Education, 2(1).

Rahardjo, M. M. (2019). Implementasi Pendekatan Saintifik Sebagai Pembentuk KeterampilanProses Sains Anak Usia Dini. Scholaria: Jurnal Pendidikan Dan Kebudayaan, 9(2), 148-159.

Rahmi, P. (2019). Pengenalan Sains Anak Melalui Permainan Berbasis Keterampilan Proses Sains Dasar. Jurnal Pendidikan, 5(2).

Rusman. (2016). Model-Model Pembelajaran Mengembangkan Profesionalisme Guru (Kedua). PT. RajaGrafindo Persada.

Saepudin, A. (2011). Pembelajaran Sains Pada Program Pendidikan Anak Usia Dini. Jurnal Teknodik, XV(2), 213-226.

Salim, E., Prasetiyawati, D., \& Hariyanti, D. (2014). Upaya Meningkatkan Kemampuan Sains Anak Melalui Metode Inkuiri Pada Kelompok B Di Tk Mojokerto 3 Kedawung Sragen Tahun Ajaran 2013/2014. Jurnal Penelitian PAUDIA, 84-111.

Suastra, I. W. (2009). Pembelajaran Sains Terkini (Mendekatkan Siswa dengan Lingkungan Alamiah dan Sosial Budayanya) (1st ed.). Universitas Pendidikan Ganesha.

Suyanto. (2008). Strategi Pendidikan Anak. Hikayat. 
Thobroni, M. (2016). Belajar dan Pembelajaran (M. Sandra (ed.); I, Cetakan). Ar-Ruzz Media.

Yulianti, D., Wiyanto, \& H., S. S. D. (2011). Model Pembelajaran Sains di Taman Kanak-Kanak dengan Bermain sambil Belajar. Jurnal Ilmu Pendidikan, 17(6), 434-438.

Zaini, A. (2019). Bermain sebagai Metode Pembelajaran bagi Anak Usia Dini. Jurnal Inovasi Pendidikan Guru Raudhatul Athfal, 3(1), 118. https://doi.org/10.21043/thufula. v3i1.4656

Zubaidah, S. (2011). Pembelajaran Sains (IPA) Sebagai Wahana Pendidikan Karakter. Seminar Nasional II "Mewujudkan Pendidik Dan Tenaga Kependidikan Yang Profesional", June, 1-10. 